\title{
ANALYTICAL THEORY : GEGAR BUDAYA (CULTURE SHOCK)
}

\author{
ANALYTICAL THEORY: CULTURAL EXTENSION (CULTURE SHOCK)
}

Oleh :

\author{
Sabrina Hasyyati Maizan ${ }^{1}$ \\ Khoiruddin Bashori ${ }^{2}$ \\ Elli Nur Hayati ${ }^{3}$
}

\begin{abstract}
Submitted:

30 Januari 2020

Revision:

11 April 2020

Accepted:

19 Mei 2020

In the current era of globalization can influence the development of technology very rapidly, people are expected to have the ability to pursue such developments to improve the capability that allows people visit or move to other areas that can support them in every aspect. The migration of people from the area of origin to new areas pose a cultural shift because of differences in language, patterns of life and religion. Such changes can lead to psychosocial stressors such as the existence of barriers in communication, feelings of alienation to be able to raise concerns on the individual, such a thing is called culture shock (culture shock). The literature review is made aimed to describe the phenomenon of culture shock (culture shock). The most prominent conclusion of describing the existing theories about culture shock is that there is a difference in name but has a theoretical or conceptual meaning is almost the same in every phase.
\end{abstract}

Keywords: analysis theory; culture extension; culture shock.

\begin{abstract}
ABSTRAK
Pada era globalisasi saat ini mampu mempengaruhi berkembangnya teknologi dengan sangat pesat, masyarakat diharapkan memiliki kemampuan untuk mengejar perkembangan tersebut untuk meningkatkan kemampuan yang memungkinkan masyarakat mendatangi atau berpindah ke daerah lain yang mampu mendukung mereka dari segala aspek. Berpindahnya masyarakat dari daerah asal ke daerah baru menimbulkan pergeseran budaya yang dikarenakan adanya perbedaan bahasa, pola kehidupan serta agama. Perubahan seperti ini dapat memicu timbulnya stressor psikososial seperti adanya hambatan dalam berkomunikasi, timbulnya perasaan terasingkan hingga mampu memunculkan kecemasan pada diri individu, hal seperti inilah yang disebut dengan gegar budaya (culture shock). Literatur review dibuat bertujuan untuk mendeskripsikan fenomena gegar budaya (culture shock). Kesimpulan yang paling menonjol dari mendeskripsikan teori teori yang ada mengenai gegar budaya ini yaitu terdapat perbedaan secara nama tetapi memiliki makna teoritik atau konseptual yang hampir sama di setiap fasenya.
\end{abstract}

Kata kunci : analisis teori; culture shock; gegar budaya.

\section{PENDAHULUAN}

Pesatnya perkembangan teknologi dan komunikasi di era globalisasi mampu mempengaruhi perkembangan pada pendidikan, ekonomi, agama, dan budaya. Hal tersebut

\footnotetext{
${ }^{1}$ Sabrina Hasyyati Maizan, Universitas Ahmad Dahlan, sabrina.maizan@gmail.com

${ }^{2}$ Khoiruddin Bashori, Universitas Ahmad Dahlan, khoiruddinbashori@gmail.com

${ }^{3}$ Elly Nur Hayati, Universitas Ahmad Dahlan, ellynurhayati@gmail.com
} 
mampu meningkatkan arus mobilitas penduduk yang semakin nyata untuk mengejar berbagai aspek pendukung kehidupan. Usaha yang dapat dilakukan individu agar mampu meningkatkan kehidupan dan mampu mengikuti perkembangan salah satunya dengan melakukan perjalanan keluar menuju daerah yang memiliki sumber-sumber lengkap dalam mendukung pemenuhan kebutuhan. Keadaan tersebut diperkuat dengan hasil penelitian Hadawiah (2019), faktor yang mendorong individu untuk merantau ke daerah yang lebih mumpuni adalah pendidikan, ekonomi, dan budaya, yangmana dari ketiga hal tersebut individu jadi memiliki harapan atau ekspektasi agar dapat menjadi lebih baik lagi dalam menggapai cita-cita dan masa depan.

Perjalanan keluar tersebut dilakukan dengan cara berpindah secara temporer maupun permanen, dari daerah satu menuju daerah lain yang memungkinkan bertemunya antara satu budaya dengan budaya lainnya. (Gaw, 2000). Sejalan dengan yang dikatakan oleh (Ward et al., 2001) gegar budaya normal terjadi pada tahun pertama individu berpindah ke daerah lain, yang mana pada tahun awal tersebut mengalami penderitaan karena adanya perbedaan budaya. Masalah ini dapat menjadi pemicu timbulnya stressor psikososial yang mampu memunculkan hambatan komunikasi, pertukaran emosi, dan lebih mendalam lagi mengakibatkan perasaan terasing yang dapat memicu kecemasan, yang mana kondisi ini disebut sebagai individu yang mengalami gegar budaya (Zhou et al., 2008).

Gegar budaya adalah reaksi individu pada lingkungan baru yang belum dikenalinya sehingga menimbulkan reaksi awal berupa cemas akibat individu kehilangan tanda - tanda yang dikenalnya di lingkungan lama (Bochner, 2003). Gegar budaya (culture shock) terjadi karena adanya ketidaksetaraan pandangan antara budaya satu dengan lainnya, sehingga membuat suatu budaya baru yang datang ke budaya lainnya mengalami kehilangan harapan atau antisipasi terhadap kesamaan (Departemen Kebudayaan dan Pariwisata, 2008). Gegar budaya juga bias diartikan sebagai keadaan dimana seseorang tidak mengenal kebiasaan sosial dari kultur baru, sehingga seorang individu tersebut tidak dapat menampilkan perilaku yang sesuai dengan aturan di lingkungan baru (Dayakisni \& Yuniardi, 2017).Perbedaan dalam cara berkomunikasi dan minimnya pemahaman dalam berbudaya juga merupakan salah satu pemicu timbulnya gegar budaya pada seorang individu yang baru berpindah ke daerah baru (Nasrullah, 2012).

Gegar budaya yang paling jarang disadari oleh makhluk sosial adalah gegar budaya dalam berbahasa, yangmana berbahasa sangat penting dalam komunikasi untuk menjalin hubungan dengan orang lain, seperti; adanya perbedaan penuturan kata, perbedaan pelafalan, perbedaan intonasi, dan adanya bahasa gaul, sehingga setiap individu yang memiliki perbedaan bahasa yang sangat signifikan akan sangat bermasalah dengan keadaan tersebut (Mayasari \& Sumadyo, 2018). Secara ringkas dapat diartkan semua bentuk stress mental maupun fisik yang dialami oleh individu pendatang selama berada di daerah asing disebut sebagai gegar budaya (culture shock) (Levy \& Shirave, 2012) Pada dasarnya gegar budaya umum terjadi pada individu rantau yang memulai kehidupan baru di dareah baru dengan situasi dan kondisi budaya yang berbeda dengan budaya aslinya. Hal tersebut memungkinkan adanya tuntutan untuk memahami budaya yang baru, dan respon yang nampak tidak selalu dapat langsung menunjukkan hasil yang sesuai dengan harapan, yangmana keadaan seperti itu disebabkan karena adanya perbedaan bahasa, adat istiadat, tata cara berkomunikasi, yangmana memerlukan proses dalam mempelajari hal baru yang kemudian akan dipahami dan diterapkan oleh individu perantau di kesehariannya (Devinta et al., 2015).

Gegar budaya dapat diatasi bila seorang individu mampu beradaptasi dan meyesuaikan diri dengan budaya tempat individu berada, sehingga terjalin komunikasi yang efektif dan lancar, perasaan lebih nyaman, serta permasalahan ketegangan akibat perbedaan budaya dapat terselesaikan (Samovar et al., 2011). Berdasarkan hasil penelitian Hasibullah (2020), upaya yang paling utama dalam mengatasi gegar budaya yaitu dengan cara melakukan 
penyesuaian diri terhadap bahasa setempat, sehingga dapat terjalin komunikasi yang baik dengan masyarakat daerah.

Penyesuaian diri merupakan salah satu syarat penting dalam terciptanya kesehatan mental individu. Ketika seorang individu mengalami ketidak mampuan dalam menyesuaikan diri terhadap lingkungannya, maka tidak jarang pula individu tersebut akan mengalami stres atau depresi. Akan tetapi, jika individu tersebut mampu menyesuaikan diri dengan baik terhadap lingkungannya maka akan tercipta individu yang mencapai keseimbangan diri dalam memenuhi kebutuhan individu maupun lingkungan. Sejalan dengan teori yang disampaikan oleh (Tallent, 1978) setiap tahap kehidupan, individu dituntut agar mampu menyesuaikan diri di lingkungan sekitarnya, bagi individu yang berhasil dalam penyesuaian diri akan mendapatkan kepuasan dalam hidupnya, tapi jika sebaliknya individu tersebut akan mengalami hambatan dalam setiap tahap kehidupan berikutnya.

Hasil penelitian (Winkelman, 1994) menjelaskan bahwa, memiliki kemampuan interaksi dan penyesuaian diri yang baik dengan memahami serta senantiasa mengamalkan budaya baru tersebut kedalam kehidupan sehari hari mampu mengatasi gegar budaya pada individu. (Gudykunst \& Kim, 2003) berpendapat sebagai makhluk sosial selayaknya memiliki interaksi di antara masyarakat, akan tetapi kemampuan individu untuk berkomunikasi sesuai dengan norma dan nilai budaya lokal tergantung dari proses penyesuaian diri atau adaptasi pendatang. Oleh sebab itu, (Hutapea, 2014) memaparkan bahwa penyesuaian diri sangat berperan dalam menurunkan stres kehidupan mahasiswa International yang bersekolah di luar negri. Sehingga, tujuan dari dibuatnya literatur review ini adalah untuk mendeskripsikan fenomena gegar budaya, dan memberikan referensi teori yang lebih banyak lagi kepada peneliti berikutnya, yangmana pada penelitian sebelumnya hanya menggunakan sedikit teori gegar budaya (culture shock) sehingga pembaca kurang mampu untuk mendapatka informasi yang kaya mengenai teori dari gegar budaya (culture shock).

\section{METODE}

Jenis penelitian ini adalah penelitian kajian literatur (literatur review), yaitu serangkaian penelitian yang menggunakan metode pengumpulan data pustaka, atau penelitian yang objeknya digali melalui berbagai informasi kepustakaan (seperti buku, jurnal ilmiah, koran, majalah, dan dokumen lainnya) (Sukmadinata \& Syaodih, 2005). Literatur review juga merupakan serangkaian kegiatan yang dilakukan dengan cara membaca, mencatat, dan mengolah bahan penulisan yang berfokus pada topik atau variable penelitian yang diminati (Nursalam, 2008). Fokus pada topik atau variable yang digunakan sebagai bahan bacaan, catatan, dan pengolahan penulisan penelitian ini adalah data-data yang membahas mengenai gegar budaya (culture shock). Data yang sudah didapat dari berbagai informasi kepustakaan tersebut dikumpulkan sebagai satu kesatuan dokumen yang digunakan untuk memecahkan topik atau variable yang telah ditentukan dengan cara mendeskripsikan (Kurnia, 2007), yang mana bahan atau data yang akan dideskripsikan adalah mengenai gegar budaya (culture shock).

\section{HASIL DAN PEMBAHASAN}

Teori gegar budaya (culture shock) pertama kali dicetuskan oleh Hall (1959), sebagai sebuah gangguan pada semua hal yang biasa dihadapi di tempat asal menjadi sangat berbeda dengan hal yang dihadapi di tempat baru dan asing. Kemudian, gegar budaya diteliti pertama kali oleh Oberg (1960), dengan menggambarkan respon yang mendalam dan menunjukkan adanya ketidakmampuan yang dialami oleh individu dalam lingkungan barunya, yangmana ketidakmampuan tersebut terjadi pada kognitif, sehingga menyebabkan gangguan pada identitas (Ting-Toomey, 1999). Gegar budaya adalah reaksi emosi terhadap perbedaan 
budaya yang tidak terduga dan terjadi kesalahpahaman pada pengalaman yang berbeda, sehingga mengakibatkan munculnya perasaan tidak berdaya, mudah terpancing emosi, takut akan dibohongi, dan dilukai serta diacuhkan (Bock, 1970; Adler, 1975; Pedersen, 1995).

Perbedaan budaya yang terjadi dapat menyebabkan terjadinya gegar budaya, yangmana gejala yang ditimbulkan berupa perasaan tidak biasa yang berdampak langsung terhadap individu seperti menjadi stress psikologis (Xia, 2009). Gegar budaya juga dapat dijelaskan dengan adanya kesenjangan antara budaya lama dengan budaya baru yang dialami oleh individu dan menyebabkan kebingungan, kemudian menimbulkan pemikiran negative terhadap keadaan baru (Lubis, 2015).

Penelitian yang dilakukan oleh Oberg (1960), menjelasakan aspek gegar budaya ; (1) Adanya ketegangan karena upaya untuk beradaptasi secara psikologis, (2) Rasa kehilangan terhadap teman, status, profesi, dan harta. (3) Ditolak atau menolak anggota budaya baru, (4) Kebingungan dalam peran, harapan dan nilai. (5) Cemas hingaa jijik dan marah saat menyadari adanya perbedaan budaya, (6) Adanya perasaan tidak berdaya karena kurang atau bahkan tidak mampu dalam mengatasi lingkungan baru.

Penelitian Hamboyan dan Bryan (1995) menyebutkan faktor yang dapat mempengaruhi gegar budaya seseorang individu seperti kesepian, kesulitan keuangan, kesalahpahaman budaya, kecurigaan, dan pengawasan akademik.

Hasil penelitian Abbasian \& Sharifi (2013) menyatakan "gegar budaya yang dialami oleh mahasiswa non Persia yang berkuliah di Universitas Ferdowsi Mashhad Iran disebabkan oleh factor keterbatasan dalam berkomunikasi (bahasa) dengan masyarakat asli dan sebaliknya, adanya perbedaan kebudayaan dan kepercayaan agama yang dianut".

Rajasekar dan Renand (2013), juga menambahkan dalam faktor gegar budaya (culture shock) yang dialami oleh individu antara lain fleksibelitas budaya, etnosentrisme, serta reaksi stres individu. Hasil penelitian dari Al-Ahtami \& Al-Ahdal (2014), menyatakan bahwa "berpindahnya siswa Arab dari negara aslinya ke Amerika membuat mereka mengalami berbagai permasalahan yang disebabkan oleh adanya perbedaan bahasa, budaya, dan nilai yang mereka percaya, sehingga membuat mereka mengalami kesulitan dalam melakukan penyesuaian diri di negara baru sehingga membuat individu mengalami gegar budaya".

Adapun penelitian dari Naeem et al (2016) faktor yang mempengaruhi dapat terjadinya gegar budaya (culture shock) adalah sikap bermusuhan dan perilaku etnosentris warga negara dari negara tuan rumah, sikap warga negara tuan rumah yang menolok-olok dari individu negara pendatang, serta kurangnya sikap saling menghargai. Pada buku yang ditulis oleh Hall (1959), dikatakan bahwa setiap yang dilakukan oleh makhluk hidup di muka bumi pasti mengsalami tahapan kehidupan yang pasti akan dilewatinya, tidak terkecuali dengan fenomena gegar budaya (culture shock) yang dialami oleh individu yang mengalami kebingungan saat berpindah dari daerah satu ke daerah lainnya yang kemudian mengalami perbedaan signifikan dengan daerah asal, yangmana tahapan tersebut digambarkan dengan; (1) The honeymoon phase, adanya perasaan bahagia ketika sampai di tempat baru (2) The crisis phase, perasaan tidak berdaya yang disebabkan karena adanya perbedaan yang sangat signifikan dengan daerah asal, namun individu akan segera melaluinya ketika individu mampu menyesuaikan diri dengan baik. (3) The adjustment place, individu mulai mampu membangun interaksi dengan lingkungan barunya. (4) Bi-cultural phase, individu merasa nyaman dengan memiliki dua kebudayaan, keadaan ini merupakan indikasi yang baik, karena individu berhasil melewati seleksi alam kecil. Akan tetapi ada juga individu yang terlalu memuja kebudayaan asing, sehingga ketika kembali ke tempat asalnya, merasa asing kembali".

Oberg (1960) menggambarkan tahapan pada gegar budaya dengan bahasa yang berbeda yaitu dengan menggunakan kata "fase", yangmana fase gegar budaya (culture shock) merupakan dampak yang disebabkan oleh tekanan saat memasuki budaya baru yang 
dikombinasikan dengan sensasi kerugian, kebingungan, dan ketidakberdayaan sebagai hasil dari kehilangan norma budaya dan ritual sosial. Fase gegar budaya digambarkan dengan $U$ Curve Hypothesis yaitu; (1) Fase Optimistik, individu merasa gembira, memiliki rasa penuh harapan dan euphoria saat baru memasuki lingkungan baru. (2) Fase Krisis, individu mulai memiliki permasalahan dengan lingkungan barunya. (3) Fase recovery, individu mulai mengerti budaya barunya, pada tahap ini individu secara bertahap membuat penyesuaian dan perubahan untuk menanggulangi budaya baru. (4) Fase penyesuaian diri, individu mampu memahami budaya barunya, ketika individu mampu menyesuaikan diri dengan dua kebudayaan yang dimilikinya, individu tersebut akan merasa puas dan menikmati dua kebudayaan yang dimiliki.

Ward et al., (2001) juga membuat tahapan dalam gegar budaya dengan menggunakan kata "dimensi", yang mana dimensi dalam gegar budaya sendiri merupakan tingkatan atau lapisan yang dialami individu saat berpindah ke suatu negara baru yang memiliki perbedaan dengan negara asal, dimensi tersebut terbagi menjadi 3 yang biasa disebut dengan $\mathrm{ABC}$ teori, yaitu; (1) Affective yaitu perasaan dan emosi yang dapat menjadi positif atau bahkan negative, dimana individu mengalami kebingungan serta merasa kewalahan karena datang ke lingkungan yang tidak dimenegrti sejak awal. (2) Behavior yaitu memahami budaya dan mengembangkan kemampuan sosial terhadap budaya baru. (3) Cognitive yaitu perubahan persepsi individu terhadap identifikasi etnis dan nilai-nilai akibat kontak budaya, serta hilangnya hal-hal yang dianggap benar oleh individu yang tidak dapat dihindarkan.

Model integrasi ABC Ward et al. tersebut mampu membantu individu yang mengalami gegar budaya (culture shock) dapat dengan bebas mengungkapkan perasaan dan emosi mereka yang telah diindikasikan dapat menjadi penyebab stres serius, individu juga harus memiliki kompetensi yang akan memungkinkan mereka untuk mampu berinteraksi dengan orang-orang dari latar belakang budaya yang berbeda, pengajaran kompetensi antar budaya melibatkan pemahaman dan kemudian berurusan dengan sikap, emosi, kepercayaan dan nilai-nilai masing-masing individu. Dalam kondisi ini, toleransi dan memiliki pikiran terbuka tentang budaya lokal mungkin lebih mudah dilakukan daripada penerimaan (Saylag, 2014).

Hasil penelitian dari Bidang et al., (2018), tahapan-tahapan yang akan dilewati oleh individu dalam proses gegar budaya adalah (1) Timbulnya stereotip negative terhadap lingkungan baru, (2) Mampu mempelajsari kenyataan tentang kebudayaan di lingkungan baru, (3) Memiliki kemampuan dalam menyatukan pandangan mengenai lingkungan asal dengan barunya. Tahapan-tahapan yang sudah atau akan dilalui oleh individu akan berjalan dengan baik jika setiap individu memiliki penerimaan di dalam dirinya, sehingga akan lebih dapat berjalan dengan lancer dalam menjalani proses dikemudiannya, hal tersebut merupakan salah satu usaha untuk mengurangi gegar budaya yang dialami oleh individu di daerah asing (Oberg, 1960). Pada hasil penelitian (Miyamoto \& Kuhlman, 2001) menyatakan pengadaan program untuk membangun hubungan yang baik antara siswa Jepang dengan guru di Amerika, dan mampu meningkatkan persahabatan antara siswa Amerika dengan Jepang merupakan upaya dalam mengurangi gegar budaya (culture shock) yang dialami oleh siswa Jepang dan membantu siswa merasa lebih nyaman, adapun mengajarkan secara mandiri kepada siswa untuk dapat beradaptasi terhadap budaya baru dengan cara memahami budaya yang berlaku.

Chapdelaine dan Alexitch (2004), juga menyatakan bahwa interaksi sosial dengan budaya tuan rumah sangat berperan penting dalam penyesuaian diri. Selain itu, memiliki banyak relasi pertemanan mampu untuk membantu dalam menyelesaikan permasalahan dalam suatu budaya (Furnham, 2004). Suatu lembaga akademik juga harus memiliki peran dalam memberikan fasilitas semacam bimbingan yang efektif agar siswa menjadi mampu dalam mempersiapkan diri untuk menghadapi gegar budaya dengan cara melakukan 
penyesuaian diri (culture shock) (Irwin, 2007). Adanya literasi budaya yang dibuat oleh lembaga daerah juga mampu dalam mengurangi gegar budaya yang dialami oleh pendatang asing, yangmana literasi budaya ini dapat mencakup mengenai pengetahuan di kebudayaan sekitar, sehingga membuat pendatang asing dapat mempelajari dan mengenali terlebih dahulu kebudayaan yang akan didatangi sebelum datang ke daerah barunya (Faizin, 2018).

Penelitian dari Suryaman (2010), menyatakan gegar budaya (culture shock) dapat diatasi dengan kemampuan dan keterampilan pribadi yang dimiliki setiap individu, kemampuan dan keterampilan pribadi yang sangat berperan tersebut adalah kemampuan melakukan penyesuaian diri, toleransi, harmoni, dan sinergi dalam berbudaya. Siregar \& Astrid (2018), menyimpulkan bahwa semakin seseorang memiliki penyesuaian diri yang tinggi, maka semakin rendah gegar budaya yang akan dialami oleh seseorang di daerah barunya. Terdapat tiga tahapan atau proses dalam penyesuaian diri yaitu; (1) Stress, (2) Adaptasi, dan (3) Growth yaitu proses pertumbuhan yang ditandai dengan naik turunnya proses stress dan adaptasi (Mulyana, 2015).

Adapun penyesuaian diri yang dapat dilakukan antara lain mampu memahami dan menguasai Bahasa setempat, melakukan pendekatan sosial dengan masyarakat sekitar, dan memiliki keterbukaan serta keinginan untuk mengenal budaya setempat (Sekeon, 2013). Kemampuan seseorang dalam pengungkapan diri terhadap keadaan di lingkungan baru juga dapat mengurangi gegar budaya (culture shock), yangmana pengungkapan diri tersebut mampu meningkatkan penyesuaian diri seorang individu (Hutabarat \& Sawitri, 2015). Selain penyesuaian diri yang berperan dalam meminimalisir terjadinya gegar budaya, dukungan sosial juga sangat berperan penting, karena disetiap keadaan yang dialami oleh makhluk sosial membutuhkan energi yang besar dari lingkungan eksternalnya yang ditunjukkan dengan adanya semangat yang didapat individu dari lingkungannya, dalam keadaan tersebut individu akan merasa lebih diterima di daerah barunya (Rizal \& Herawati, 2020).

\section{KESIMPULAN}

Gegar budaya atau cultur shock merupakan reaksi emosi negatif yang dirasakan oleh individu ketika berpindah ke budaya baru yang sangat berbeda dengan budaya asalnya. Gegar budaya disebabkan oleh kurangnya pengetahuan dan pandangan negative terhadap budaya barunya, adanya perbedaan bahasa, nilai dan keyakinan antara budaya asal dengan budaya barunya, adanya diskriminasi dan sikap tidak diharagai oleh warga negara tuan rumah, serta adanya perasaan kesepian dan kesulitan ekonomi yang dialami oleh ekspektariat. Literatur ini diharapkan dapat memperkaya pengetahuan dalam bidang psikologi, khususnya psikologi klinis yang kaitannya dengan psikologi budaya yaitu memberi gambaran bahwa gegar budaya mampu mempengaruhi tingkat stres individu apabila tidak mampu menyesuaikan dengan budaya barunya.

\section{DAFTAR PUSTAKA}

Al-Ahtami, A., \& Al-Ahdal, A. (2014). Academic and Social Adjustments of Arab Fulbright Students in American Universities: A Case Study. International Journal of Humanities and Social Science, 4(5), 216-222.

Abbasian, F., \& Sharifi, S. (2013). The Relationship between Culture Shock and Sociolinguistic Shock: A Case Study of Non-Persian Speaking Learners. Open Journal of Social Science Research, 1(6), 154. DOI: 10.12966/ojssr.09.07.2013.

Adler, P. S. (1975). The Transitional Experience: An Alternative View of Culture Shock. 
Journal of Humanistic Psychology, 15(4), 13-23.

Bidang, A. S., Erawan, E., \& Sary, K. A. (2018). Proses Adaptasi Mahasiswa Perantauan Dalam Menghadapi Gegar Budaya. EJournal Ilmu Komunikasi, 6(3), 212-225.

Bochner, S. (2003). Culture Shock Due to Contact with Unfamiliar Cultures. Online Readings in Psychology and Culture, 8(1), 1-12.

Bock, P. K. (1970). Culture shock: a reader in modern cultural anthropology. New York: Knopf.

Chapdelaine, R. F., \& Alexitch, L. R. (2004). Social skills difficulty: Model of culture shock for international graduate students. Journal of College Student Development, 45(2), 167-184. DOI: 10.1353/csd.2004.0021.

Dayakisni, T., \& Yuniardi, S. (2017). Psikologi Lintas Budaya (Edisi Revisi). Malang: UMM Press.

Devinta, M., Hidayah, N., \& Hendrastomo, G. (2015). Fenomena Culture Shock (Gegar Budaya) pada Mahasiswa Perantauan di Yogyakarta. Jurnal Pendidikan Sosiologi 2015, $1-15$.

Departemen Kebudayaan dan Pariwisata. (2008). Pendidikan Multikultural dan Revitalisasi Hukum Adat dalam Perspektif Sejarah. Departemen Kebudayaan dan Pariwisata.

Faizin. (2018). Literasi Budaya Lokal Untuk Meminimalisir Gegar Budaya Pemelajar Bipa. Prosiding SENASBASA, 116-124.

Furnham, A. (2004). Foreign students: Education and culture shock. Psychologist, 17(1), 1619.

Gaw, K. F. (2000). Reverse culture shock in students returning from overseas. International Journal of Intercultural Relations, 24(1), 83-104.

Gudykunst, W. B., \& Kim, Y. Y. (2003). Communicating with Strangers: An Approach to Intercultural Communication. New York: McGraw-Hill.

Hadawiah, H. (2019). Fenomena (Gegar Budaya) Pada Mahasiswa Perantauan Di Universitas Muslim Indonesia. Al-MUNZIR, 12(1), 149-164.

Hall, Edward. T. (1959). The Silent Language. New York: Doubleday.

Hamboyan, H., \& Bryan, A. K. (1995). International students. Culture shock can affect the health of students from abroad. Canadian Family Physician Médecin de Famille Canadien, 41, 1713-1716.

Hasibullah, M. W. (2020). Proses Gegar Budaya dalam Komunikasi Antarbudaya pada Pengungsi Laki-Laki Afghanistan di Kota Medan. Thesis. Universitas Sumatera Utara.

Hutabarat, Y., \& Sawitri, D. (2015). Hubungan Antara Gegar Budaya Dengan Pengungkapan Diri Pada Mahasiswa Tahun Pertama Bersuku Batak Di Universitas Diponegoro. Empati, 4(2), 153-157.

Hutapea, B. (2014). Life Stress, Religiosity, and Personal Adjustment of Indonesian as International Students. Makara Human Behavior Studies in Asia, 18(1), 25. DOI: 10.7454/mssh.v18i1.3459.

Irwin, R. (2007). Culture shock: Negotiating Feelings in the Field. Anthropology Matters, 9(1), 1-11.

Kurnia, S. S. (2007). Menulis ilmiah: metode penelitian kualitatif. Jakarta: Yayasan Obor Indonesia.

Levy, D. A., \& Shirave, E. B. (2012). Psikologi Lintas Kultural: Pemikiran Kritis dan Terapan Modern. Jakarta, Indonesia : Kencana.

Lubis, R. (2015). Sosiologi Agama: Memahami Perkembangan Agama dalam Interaksi Sosial. Jakarta, Indonesia : Kencana.

Mayasari, I., \& Sumadyo, B. (2018). Culture Shock ( Gegar Budaya ) Penutur Jawa Dan Jakarta: Jurnal Lentera, 1(2), 7-20.

Miyamoto, Y., \& Kuhlman, N. (2001). Ameliorating culture shock in Japanese expatriate 
children in the US. International Journal of Intercultural Relations, 25(1), 21-40. DOI :10.1016/S0147-1767(00)00040-7.

Mulyana, D. (2015). Komunikasi Lintas Budaya: Pemikiran, Perjalanan dan Khayalan (Edisi Revisi). Bandung: PT Remaja Rosdakarya.

Naeem, A., Nadeem, A., \& Khan, I. U. (2016). Culture Shock and Its effects on Expatriates

Full Length Research Paper Culture Shock and Its effects on Expatriates. 4(6), 248258.

Nasrullah, R. (2012). Komunikasi Antarbudaya di Era Budaya Siber (Pertama). Jakarta, Indonesia : Kencana.

Nursalam .(2008). Konsep \& Metode Keperawatan (ed. 2). Jakarta: Salemba Medika.

Oberg, K. (1960). Symptoms of Culture Shock. Practical Anthropology, 177-182.

Pedersen, P. (1995). The Five Stages of Culture Shock: Critical Incidents Around the World. Amerika: Greenwood Press.

Rajasekar, J., \& Renand, F. (2013). Culture Shock in a Global World: Factors Affecting Culture Shock Experienced by Expatriates in Oman and Omani Expatriates Abroad. International Journal of Business and Management, 8(13), 144-160. DOI:10.5539/ijbm.v8n13p144.

Rizal, I., \& Herawati, I. (2020). Gegar Budaya Ditinjau dari Dukungan Sosial pada Mahasiswa Thailand Selatan (Patani). Journal An-Nafs: Kajian Penelitian Psikologi, 5(1), 89-100. DOI: 10.33367/psi.v5i1.1081.

Samovar, L. A., Porter, R. E., \& McDaniel, E. R. (2011). Intercultural Communication: A Reader. Amerika: Cengage Learning.

Saylag, R. (2014). Culture Shock an Obstacle for EFL Learners. Procedia - Social and Behavioral Sciences, 114, 533-537. DOI:10.1016/j.sbspro.2013.12.742.

Sekeon, K. (2013). Komunikasi Antar Budaya pada Mahasiswa FISIP UNSRAT. Jurnal Acta Diurna, 2(3), 1-14.

Siregar, A. O. A., \& Kustanti, E. R.. (2018). Hubungan Antara Gegar Budaya Dengan Penyesuaian Diri Pada Mahasiswa Bersuku Minang Di Universitas Diponegoro. Empati, 7(2), 48-65.

Sukmadinata, \& Syaodih, N. (2005). Metode Penelitian Pendidikan. Bandung: PT Remaja Rosdakarya.

Suryaman. (2010). Analisis Kepemimpinan Multikultural di Sekolah Menengah dalam Upaya Mencegah Fenomena Gegar Budaya: Konteks Indonesia. Sosiohumanika, 3(1), 109122.

Tallent, N. (1978). Psychology of Adjustment: Understanding Ourselves and Others. New York: David Van Nostrand.

Ting-Toomey, S. (1999). Communicating Across Cultures. New York: Guilford Press.

Ward, C., Bochner, S., \& Furnham, A. (2001). The Psychology of Culture Shock. USA: Routladge.

Winkelman, M. (1994). Cultural Shock and Adaptation. Journal of Counseling \& Development, 73(2), 121-126.

Xia, J. (2009). Analysis of Impact of Culture Shock on Individual Psychology. International Journal of Psychological Studies, 1(2), 97. DOI: 10.5539/ijps.v1n2p97.

Zhou, Y., Jindal-Snape, D., Topping, K., \& Todman, J. (2008). Theoretical models of culture shock and adaptation in international students in higher education. Studies in Higher Education, 33(1), 63-75. DOI: 10.1080/03075070701794833. 